\title{
The effect of fertilization and crop rotation on soil chemi- cal and biological properties. Field trials on a clay soil in Southern Finland
}

\author{
AILA METTÄLÄ \\ Department of Microbiology, University of Helsinki 00710 Helsinki 71, \\ Finland
}

MAARIT KOPONEN

Department of Agricultural Chemistry, University of Helsinki, 00710 Helsinki 71, Finland

HEIKKI PIRINEN

Department of Microbiology, University of Helsinki 00710 Helsinki 71, Finland

\section{JOHAN KORKMAN}

Kemira Oy, P. O. Box 330, 00101 Helsinki 10, Finland

\footnotetext{
Abstract. The effects of prolonged fertilizer use and crop rotation on microbial biomass and activity and nitrogen content in a clay soil in Southern Finland were investigated.

Neither fertilization nor crop rotation had any lasting effect on the level of inorganic nitrogen: the low level observed in the spring before fertilization was found again in the autumn in both a monoculture and a rotation, irrespective of the fertilization level. The clover-grass ley nevertheless had a residual effect on yield, as the average yield over the total trial period was higher in the rotation. Even in the second year after the clover-grass ley, nearly double the quantity of nitrogen was mobilized in unfertilized plots as compared with the monoculture: $36.8 \mathrm{~kg} / \mathrm{ha}$ and $21.0 \mathrm{~kg} / \mathrm{ha}$, respectively.

Fertilization resulted in a slight increase in the abundance and activity of microbes. An increasing effect on straw decomposition was found up to the highest level of fertilization. Decomposition was equally effective in monoculture and rotation. At different levels of fertilization $(0,400,800$ and $1200 \mathrm{~kg} /$ ha NPK containing $15 \% \mathrm{~N}$ ), an average of $24,29,34$ and 38 per cent of the straw was decomposed during the growing season in the monoculture, and 25, 28, 32 and 37 per cent in the rotation. Carbon dioxide evolved during the growing seasons in unfertilized plots at the rate of $4.3 \mathrm{mmol} / \mathrm{m}^{2} / \mathrm{h}$ in monoculture and $4.9 \mathrm{mmol} / \mathrm{m}^{2} / \mathrm{h}$ in rotation. At a fertilizer level of $400 \mathrm{~kg} / \mathrm{hat}$ the rates were 4.7 and $5.3 \mathrm{mmol} / \mathrm{m}^{2} / \mathrm{h}$ in monoculture and rotation, respectively. Maximum carbon dioxide was evolved at fertilization levels of 800 and $1200 \mathrm{~kg} / \mathrm{ha}: 5.0 \mathrm{mmol} / \mathrm{m}^{2} / \mathrm{h}$ the monoculture and $5.8 \mathrm{mmol} / \mathrm{m}^{2} / \mathrm{h}$ in the rotation. Maximum ATP content and dehydrogenase activity were observed at the fertilization levels of 400 and $800 \mathrm{~kg} / \mathrm{ha}$ and were slightly greater in the rotation than in the monoculture. Fertilization and crop rotation increased the soil microbial activity and biomass by a few ten per cent.

In this trial, favourable conditions for plant growth were also found to favour microbial activity.
} 


\section{Introduction}

One of the important cropping systems in modern farming is monoculture cultivation coupled with the abundant application of fertilizers. With the decreased use of organic waste materials it has been suggested that such a cultivation method may be detrimental to soil biological activity (PERSSON 1978). The possibility of monoculture cultivation or fertilizer application leading to a reduction in microbial activity has been studied in extended monoculture trials (MÜLLER et al. 1979). Microorganisms are essential to soil fertility as the chief agents in the decomposition of plant materials and nutrient recycling, and they can also transform nutrients added through fertilizers.

The inorganic nitrogen level of cultivated soil is generally low in spring. After fertilizer application, nitrate and ammonium nitrogen levels increase appreciably, but decrease rapidly again owing to nitrogen uptake by plants, microbial activity and abiotic factors. If a clover-grass ley is included in the crop rotation, nitrogen mineralizes from the decomposing ley residues during the course of the growing season. In particular, after a clover ley, crop yield is somewhat higher than in monoculture cultivation. This is thought mainly to be due to an improved nitrogen condition, a residual effect of the ley.

Numerous investigations have shown that NPK fertilization increases the microbial activity and biomass of cultivated soil. Its effect is usually of the order of a few ten per cent compared with the unfertilized control (ABD-ELMALEK et al. 1976, MÜLLER et al. 1979, EILAND 1980). Correlations between the soil microbial condition and fertility have been sought in an effort to devise tests through which soil fertility could be assessed. Vastly different results have been obtained in such trials because the test conditions, cultivation methods and crops employed, as well as soil and climate, have varied (JÄGGI 1974, ABD-EL-MALEK et al. 1976, VERSTRAETE \& VOETS 1977).

In the present investigation, the effects of extended fertilizer use and crop rotation on microbial activity and biomass and nitrogen content in the soil were studied. Fertilizer levels corresponding to those in normal use, and a fertilizer level exceeding the recommended, were employed. The effects of fertilization and crop rotation were studied under similar conditions from both chemical and microbiological standpoints.

\section{Materials and methods}

A fertilizer and crop rotation trial on the Kemira Oy experimental farm at Vihti, in Southern Finland, was studied between 1979 and 1981. The trial, established in 1966, comprised a spring wheat monoculture and a crop rotation of clover-timothy ley and spring wheat. The experimental field was under clover-timothy ley during 1967-68, 1972-73 and 1977-78. 1979-81 spring wheat was grown on the whole trial area. 
After 1976 fertilizer levels were $0,400,800$ and $1200 \mathrm{~kg} / \mathrm{ha} \mathrm{NPK}$, in 1976 and before they were $0,300,600$ and $1200 \mathrm{~kg} / \mathrm{ha}$. The nutrient content of the fertilizers had varied during the experiment: in 1967-70 NPK (15-9-12) was used, in 1971-72 NPK (15-11-8), in 1973-75 NPK (15-7-12), in 1976-79 NPK (15-9-12), in 1980-81 NPK (16-7-13). In $19706600 \mathrm{~kg} /$ ha lime was used as well.

Composition of the plough layer according to particle size composition was as follows: sand $1 \%$, fine sand $2 \%$, finer fine sand $10 \%$, silt $32 \%$ and clay $55 \%$. The soil $\mathrm{pH}_{\mathrm{CaCl}}$, was 4.9-5.2. The organic matter content in different plots varied between 4.9 and $8.8 \%$. In regard to total nitrogen, the field was homogeneous $(0.3 \%)$.

Grain yield and the protein content had been monitored throughout the trial. Soil calcium, potassium and phosphorus contents were measured in 1966 and 1979 . The nutrient contents were as follows $(\mathrm{mg} / \mathrm{l})$ :

\begin{tabular}{rrrrrrrr}
\hline $\begin{array}{c}\text { Fertilization } \\
\mathrm{kg} / \mathrm{ha}\end{array}$ & year & $\mathrm{Ca}$ & $\begin{array}{c}\text { Monoculture } \\
\mathrm{K}\end{array}$ & $\mathrm{P}$ & $\mathrm{Ca}$ & $\begin{array}{c}\text { Rotation } \\
\mathrm{K}\end{array}$ & $\mathrm{P}$ \\
\hline \multirow{2}{*}{$\mathrm{O}$} & 1966 & 3050 & 153 & 7.9 & 3050 & 153 & 7.9 \\
& 1979 & 4120 & 160 & 4.3 & 4010 & 136 & 4.9 \\
\multirow{3}{*}{400} & 1966 & 3025 & 158 & 8.3 & 3025 & 158 & 8.3 \\
& 1979 & 4100 & 176 & 5.5 & 3820 & 139 & 5.3 \\
\multirow{3}{*}{800} & 1966 & 2963 & 163 & 8.3 & 2963 & 163 & 8.9 \\
& 1979 & 3875 & 203 & 8.6 & 3945 & 162 & 9.8 \\
1200 & 1966 & 3000 & 151 & 8.6 & 3000 & 151 & 8.6 \\
& 1979 & 4000 & 225 & 15.0 & 3710 & 205 & 14.0 \\
\hline
\end{tabular}

The calcium content increased as a result of the liming in 1970 , but differences in the trial plots were slight. There was less potassium in the rotation than in the monoculture, which received recycled potassium from ploughed-under straw. Potassium contents increased to some extent at the highest fertilization levels. The phosphorus content decreased during the trial

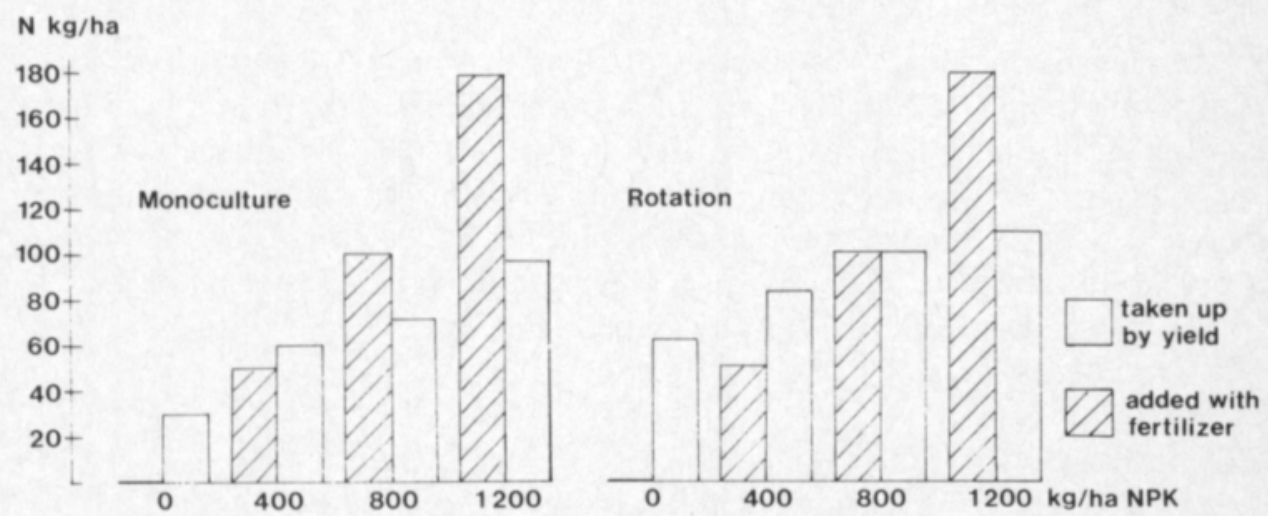

Fig. 1. Nitrogen uptake by spring wheat and nitrogen added through fertilizers in $\mathrm{kg} / \mathrm{ha}$ on average over the years $1966-81$. 
in unfertilized plots and plots treated with $400 \mathrm{~kg} / \mathrm{ha}$, and increased in maximally fertilized plots.

The amounts of nitrogen added through fertilizer and utilized by the crop are presented in Fig. 1. The values are averages taken over the entire period of the trial, 1966-81. Only those years have been included during which the entire field was under spring wheat. In unfertilized plots, the nitrogen requirement of the crop was obtained almost completely from the nitrogen store of the soil. The same was partly true at a fertilizer level of $400 \mathrm{~kg} / \mathrm{ha}$, especially in the rotation. The amount of fertilizer nitrogen exceeded the nitrogen requirement of the crop at the two highest fertilization levels. Nitrogen uptake by the wheat, depending on the level of fertilization, was $14-94 \%$ greater in the rotation than in the monoculture. The average grain yield over the period $1966-81$ was as follows $(\mathrm{kg} / \mathrm{ha})$ :

\begin{tabular}{rcc}
\hline $\begin{array}{c}\text { Fertilization } \\
\mathrm{kg} / \mathrm{ha}\end{array}$ & Monoculture & Rotation \\
\hline 0 & 1720 & 2330 \\
400 & 3120 & 3590 \\
800 & 3670 & 4070 \\
1200 & 3830 & 3990 \\
\hline
\end{tabular}

Together the nutrient analyses of the soil and crop yields show the phosphorus and nitrogen contents of unfertilized plots to have decreased during the trial. The 30-60 nitrogen kilo removal per hectare per year did not affect the total soil nitrogen at the two lowest levels of fertilization. Nor did the $70-80 \mathrm{~kg} / \mathrm{ha}$ of nitrogen exceeding the crop requirement at the highest level of fertilization have an effect on the total nitrogen content. On the other hand, potassium and phosphorus both accumulated in the soil at the highest fertilization level.

Soil samples

During the period 1979-81 a set of samples was taken with a soil corer from a depth of $0-20 \mathrm{~cm}$ on each plot. The samples of each set were then combined. For chemical analyses, the soil was air-dried. For microbiological analyses, part of the fresh combined sample was packed in plastic bags and stored at $+4^{\circ}$ C. Samples were taken 9 times in 1979,7 times in 1980 and 6 times in 1981. The first samples of the growing season were taken before combined-drilling, the last samples immediately after harvesting.

Chemical analyses

Organic carbon was determined by the wet combustion method (ALTEN et al. 1935). 
Nitrate and ammonium nitrogen were determined from a calcium sulphate extract $\left(20 \mathrm{ml}\right.$ soil and $100 \mathrm{ml}$ saturated $\mathrm{CaSO}_{4}$ solution) with nitrate and ammonium specific electrodes.

Mobilizable nitrogen was determined by incubating moist soil $(40 \mathrm{ml}$ soil and $10 \mathrm{ml}$ water) for $14 \mathrm{~d}$ at $+20^{\circ} \mathrm{C}$. Nitrate and ammonium contents were measured with specific electrodes. The significance of differences in nitrogen contents was tested by Duncan's Test (STEEL \& TORRIE 1960).

\section{Microbiological analyses}

The amount of microbial ATP (adenosine triphosphate) was determined with a Lumac Celltester M 1080 luminescence photometer (ANON. 1979).

The evolution of carbon dioxide was determined in the field by the method of WITKAMP (1966) every two weeks.

Dehydrogenase activity was determined by the method of THALMANN (1968), except that $94 \%$ ethanol was used instead of acetone and carbon tetrachloride.

Straw and cellulose decomposition: $2 \mathrm{~g}$ of air dry wheat straw or a strip of bleached sulphite cellulose was enclosed in a nylon bag. Ten bags containing straw and ten containing cellulose were buried in the plough layer of each plot for the lenght of the growing season. The loss in weight was determined.

The total bacteria were determined on soil extract agar (TAYLOR 1951) and fluorescent pseudomonads on selective agar (SIMON et al. 1973). All microbiological determinations were made within three days of sampling.

ATP content, dehydrogenase activity and bacterial numbers were calculated per gramme of dry soil, carbon dioxide evolution as $\mathrm{mmol} / \mathrm{m}^{2} / \mathrm{h}$, and straw and cellulose decomposition as the proportion of decayed material relative to the original material. The significance of differences was tested using analysis of variance.

\section{Results}

\section{Chemical analyses}

Amounts of nitrate nitrogen and ammonium nitrogen in the plough layer

The nitrate and ammonium nitrogen contents of the plough layer were determined in 1979-80. The results are presented in Fig. 2 as totalled nitrate and ammonium nitrogen. The nitrogen contents were lowest in the spring before fertilization and in the autumn after harvesting, and not appreciably different at these two times. In unfertilized plots, inorganic nitrogen content remained low throughout the growing season, though a slight increase was detected in June-July. In fertilized plots in 1979, two peaks were observed in the nitrogen content: the first immediately subsequent to fertilization and the other towards the end of June and beginning of July. In 1980, when samples 


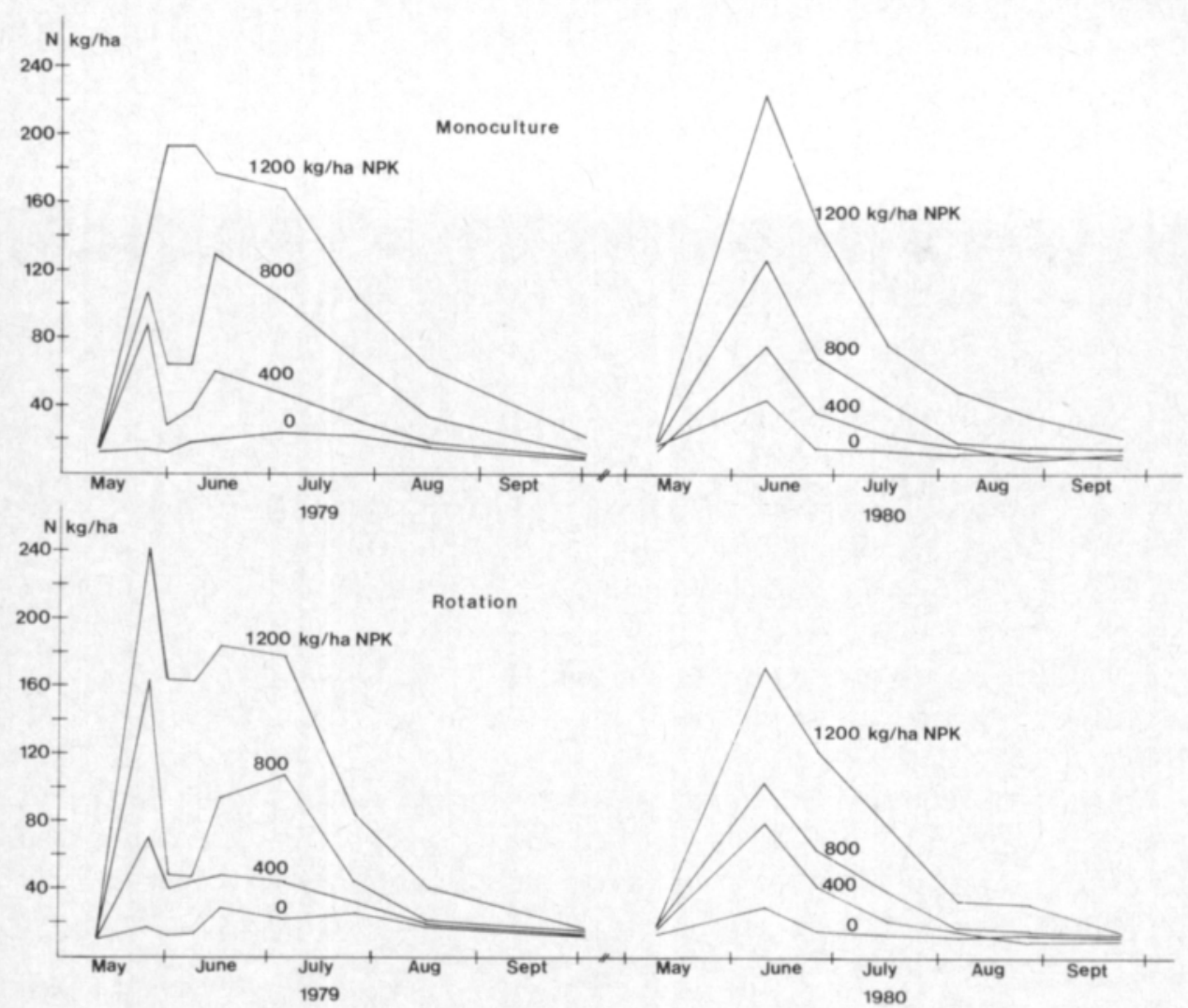

Fig. 2. Totalled nitrate and ammonium nitrogen in the plough layer $(20 \mathrm{~cm})$.

were not taken as often as in the previous year, only a post-fertilization peak was detected.

Differences between trial plots were most pronounced at the beginning of the summer, when inorganic nitrogen present in the soil was at a maximum. The differences levelled out in the course of the growing season, and towards the end of July and beginning of August only the nitrate content at the highest level of fertilization differed from the rest. The content of ammonium nitrogen was consistently smaller than that of nitrate nitrogen, and levelled out more rapidly than did the nitrate. The analyzed nitrogen contents were approximately the same in the monoculture and the rotation.

Soil mobilizable nitrogen

Nitrogen mobilization was determined from samples taken in 1980 before fertilization. The accompanying values have been obtained by subtracting the nitrogen originally present in inorganic form from the inorganic nitrogen content obtained after incubation, the results being given as $\mathrm{kg} / \mathrm{ha}$ in the plough layer. Values that have the same letter as an upper index are not significantly different at $\mathrm{p}=0.05$. 


\begin{tabular}{rcc}
\hline $\begin{array}{c}\text { Fertilization } \\
\mathrm{kg} / \mathrm{ha}\end{array}$ & $\begin{array}{c}\text { Monoculture } \\
\mathrm{N} \mathrm{kg} / \mathrm{ha}\end{array}$ & $\begin{array}{c}\text { Rotation } \\
\mathrm{N} \mathrm{kg} / \mathrm{ha}\end{array}$ \\
\hline 0 & $21.0^{\mathrm{d}}$ & $36.8^{\mathrm{a}}$ \\
400 & $31.6^{\mathrm{abc}}$ & $33.6^{\mathrm{bb}}$ \\
800 & $32.4^{\mathrm{bbc}}$ & $26.0^{\text {cd }}$ \\
1200 & $28.6^{\mathrm{bc}}$ & $32.0^{\mathrm{abc}}$ \\
\hline
\end{tabular}

Differences between the different fertilization levels were slight. However, it is of interest that in the unfertilized plots with rotated crops, nitrogen mobilized most vigorously, and in unfertilized plots under monoculture least actively.

\section{Organic matter content}

Figure 3 shows the percentage content of organic matter in a plot simulating the experimental field. Organic matter in the first replicate of the monoculture exceeded that in the second by several per cent. Since the same phenomenon had been observed previously during the trial, it seems likely that the differences were present in the soil before the trial commenced. The effect of the cultivation methods on organic matter content was therefore not assessed.

Fig. 3. Soil organic matter content (\%).

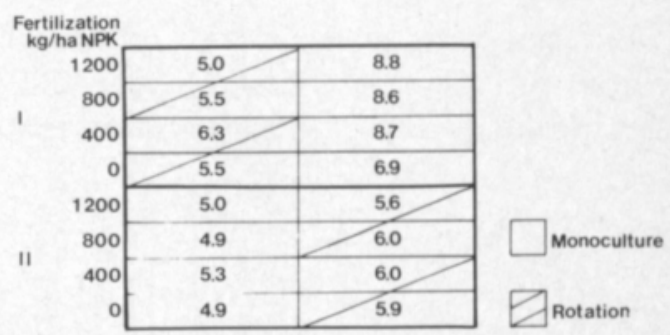

\section{Microbiological analyses}

The results of microbiological determinations are presented in Tables 1 and 2 as averages for each growing season. The ATP contents and rates of carbon dioxide evolution measured during one growing season differed by a factor of 5 in some cases, depending on the time of year samples were taken. Similarly dehydrogenase activities differed by as much as a factor of 3 and total bacterial counts by a factor of 10 . The amount of fluorescent pseudomonads ranged between $10^{4}$ and $10^{6} \mathrm{CFU}$ (colony forming unit) per gramme of soil. 
Fertilizer application increased the ATP content to some extent up to an application level of $800 \mathrm{~kg} / \mathrm{ha}$ in both the monoculture and the rotation. Exceptionally, in 1980 the highest ATP content in the rotation was obtained at the fertilization level of $1200 \mathrm{~kg} / \mathrm{ha}$ (Table 1).

Table 1. Average amounts of ATP during the growing seasons 1979-81.

\begin{tabular}{|c|c|c|c|c|c|c|}
\hline $\begin{array}{c}\text { Fertilization } \\
\qquad \mathrm{kg} / \mathrm{ha}\end{array}$ & \multicolumn{2}{|c|}{1979} & \multicolumn{2}{|c|}{1980} & \multicolumn{2}{|c|}{1981} \\
\hline Monoculture & $\mathrm{ng} / \mathrm{g}$ & RV & $\mathrm{ng} / \mathrm{g}$ & RV & $\mathrm{ng} / \mathrm{g}$ & RV \\
\hline 0 & 760 & 100 & 4490 & 100 & 580 & 100 \\
\hline 400 & 810 & 107 & 5150 & 115 & 620 & 107 \\
\hline 800 & 870 & 114 & 5840 & 130 & 640 & 110 \\
\hline 1200 & 860 & 113 & 5410 & 120 & 630 & 109 \\
\hline \multicolumn{7}{|l|}{ Rotation } \\
\hline 0 & 870 & 114 & 5540 & 123 & 630 & 109 \\
\hline 400 & 910 & 120 & 5540 & 123 & 690 & 119 \\
\hline 800 & 980 & 129 & 5730 & 128 & 730 & 126 \\
\hline 1200 & 900 & 118 & 6180 & 138 & 610 & 105 \\
\hline
\end{tabular}

$\mathrm{RV}=$ relative value

Since ATP contents were appreciably higher in 1980 than in other years, the ATP contents were converted into relative values (the ATP content of the unfertilized plot in the monoculture $=100$ ). Expressed as relative values, the effect of fertilization was approximately the same each year. Statistically significant differences were not observed between fertilization levels or cultivation methods. However, the ATP content was somewhat, though not significantly, greater in the rotation than in the monoculture.

\section{Evolution of carbon dioxide}

The effect of fertilization on carbon dioxide release was basically the same as its effect on ATP content: maximum carbon dioxide was evolved at the fertilization level of $800 \mathrm{~kg} / \mathrm{ha}$ (Table 2). More carbon dioxide was released in the rotation than in the monoculture, and in 1980 the difference was statistically significant at $p=0.05$. The rates of evolution measured in 1981 were reduced by a high level of rainfall which made the soil anaerobic.

\section{Dehydrogenase activity}

Dehyrogenase activities were clearly higher in the rotation than in the monoculture on unfertilized plots, and the difference was highly significant $(p=0.01)$. The activities were lowest at the highest fertilization level in the rotation, and the difference between unfertilized plots and plots treated with 
Table 2. $\mathrm{CO}_{2}$ evolution, dehydrogenase activity, decomposition of straw and cellulose, and bacterial numbers on average over the growing seasons 1979-81.

\begin{tabular}{|c|c|c|c|c|c|c|c|c|c|c|c|c|}
\hline \multirow{2}{*}{$\begin{array}{c}\begin{array}{c}\text { Fertilization } \\
\mathrm{kg} / \mathrm{ha}\end{array} \\
\text { Monoculture }\end{array}$} & \multicolumn{3}{|c|}{$\begin{array}{l}\mathrm{CO}_{2} \text { evolution } \\
\mathrm{mmol} / \mathrm{m}^{2} / \mathrm{h}\end{array}$} & \multicolumn{3}{|c|}{$\begin{array}{c}\text { DH activity } \\
\mu \mathrm{g} \text { TPF/g/24h }\end{array}$} & \multicolumn{3}{|c|}{$\begin{array}{l}\text { Decomposition } \\
\text { of straw, \% }\end{array}$} & \multirow{2}{*}{$\begin{array}{c}\text { Decomposition } \\
\text { of cellulose, \% } \\
1979\end{array}$} & \multirow{2}{*}{$\begin{array}{c}\text { Total bacteria } \\
\times 10^{8} \mathrm{CFU} / \mathrm{g} \\
1980\end{array}$} & \multirow{2}{*}{$\begin{array}{c}\begin{array}{c}\text { Fluorescent } \\
\text { pseudomonads } \\
\times 10^{5} \mathrm{CFU} / \mathrm{g}\end{array} \\
1980\end{array}$} \\
\hline & 1979 & 1980 & 1981 & 1979 & 1980 & 1981 & 1979 & 1980 & 1981 & & & \\
\hline 0 & 4.8 & 7.1 & 0.9 & 24.9 & 17.0 & 26.4 & 26.9 & 26.8 & 18.5 & 34.3 & 1.0 & 0.3 \\
\hline 400 & 4.9 & 8.0 & 1.1 & 29.6 & 20.8 & 29.0 & 33.4 & 27.7 & 25.3 & 43.4 & 0.9 & 0.9 \\
\hline 800 & 5.5 & 8.4 & 1.1 & 28.2 & 20.7 & 33.7 & 42.5 & 31.6 & 28.8 & 43.8 & 1.1 & 1.7 \\
\hline 1200 & 5.4 & 8.4 & 1.3 & 24.9 & 18.6 & 29.0 & 43.9 & 36.2 & 35.0 & 38.8 & 1.3 & 3.5 \\
\hline \multicolumn{13}{|l|}{ Rotation } \\
\hline 0 & 5.5 & 8.2 & 0.9 & 35.6 & 26.6 & 35.3 & 28.3 & 26.3 & 19.0 & 50.0 & 1.0 & 0.5 \\
\hline 400 & 5.4 & 9.2 & 1.2 & 36.0 & 26.3 & 38.0 & 33.2 & 26.4 & 23.3 & 44.7 & 1.0 & 1.7 \\
\hline 800 & 5.9 & 10.3 & 1.3 & 33.2 & 22.8 & 30.5 & 36.7 & 32.5 & 27.5 & 44.9 & 0.9 & 1.0 \\
\hline 1200 & 6.6 & 9.3 & 1.1 & 20.6 & 19.1 & 25.1 & 42.7 & 35.7 & 33.5 & 42.9 & 1.2 & 2.0 \\
\hline \multicolumn{13}{|l|}{ F value } \\
\hline $\begin{array}{l}\text { Rotation/ } \\
\text { Monoculture }\end{array}$ & \multirow{2}{*}{\multicolumn{3}{|c|}{$7.11^{\circ}(1980)$}} & \multicolumn{3}{|c|}{$11.38^{5011}(\mathrm{Okg} / \mathrm{ha})$} & & & & \multirow[t]{2}{*}{$8.28^{*}$} & & \\
\hline Fertilization & & & & $12.37^{\circ}$ & (rotat) & & $53.37^{\circ}$ & & & & & \\
\hline
\end{tabular}

DH activity $=$ dehydrogenase activity, $", * n, * 0 *=$ differences significant at $p=0.05,0.01,0.001$, respectively.

the highest fertilization rate was highly significant $(p=0.01)$ (Table 2). The annual differences in dehydrogenase activities were small: the activity was lower in 1980 but it was determined only twice during the growing season.

Decomposition of straw and cellulose

Fertilization promoted straw decomposition appreciably up to a fertilization level of $1200 \mathrm{~kg} / \mathrm{ha}$. There was no striking difference between the monoculture and the rotated crops (Table 2). At fertilization levels 800 and $1200 \mathrm{~kg} / \mathrm{ha}$, the effect of fertilization was statistically highly significant $(p=0.001)$. Average decomposition percentages differed to some extent in different years, partly because the lenght of the trial period varied.

The decomposition of cellulose was studied only in 1979. The results differed from the foregoing in that there was a significant difference in favour of the rotation $(p=0.05)$. In crop rotation, cellulose decomposition was slower on fertilized plots than on unfertilized plots (Table 2).

\section{Total bacteria and fluorescent pseudomonads}

Bacterial counts were made only in 1980 . Fertilization had no effect on total numbers in either cultivation. Fertilization increased the counts of fluorescent pseudomonads appreciably in the monoculture right up to the highest fertilization level. In the rotation the increase was smaller (Table 2).

Correlation between microbiological test results

Correlations between the methods were calculated using the averages over the growing season for each plot. With the exception of the correlation 
between ATP content and carbon dioxide evolution, the results of the microbiological determinations were not significantly correlated with each other (Table 3).

Table 3. Correlations between microbiological tests.

\begin{tabular}{lrrrr} 
& $\begin{array}{c}\mathrm{CO}_{2} \\
\mathrm{n}=24\end{array}$ & $\begin{array}{c}\mathrm{DH} \\
\mathrm{n}=24\end{array}$ & $\begin{array}{c}\text { Straw } \\
\mathrm{n}=24\end{array}$ & $\begin{array}{c}\text { Cellulose } \\
\mathrm{n}=8\end{array}$ \\
& & & & \\
& & & & \\
$\mathrm{ATP}$ & $0.837^{w * n}$ & 0.186 & -0.058 & 0.586 \\
$\mathrm{CO}_{2}$ & & -0.408 & 0.221 & 0.369 \\
$\mathrm{DH}$ & & & -0.279 & 0.667 \\
Straw & & & & -0.037 \\
\hline
\end{tabular}

$\mathrm{DH}=$ dehydrogenase activity, $* * \|=$ correlation significant at $\mathrm{p}=0.001$

\section{Discussion}

The effect of fertilization on the soil nitrogen level in the plough layer was apparent a few weeks after fertilizer application. During this time plants took up a large proportion of the nitrogen they used over the whole growing season. Mineral nitrogen content was very low in the spring before fertilization and, with the exception of the highest fertilization level in the rotation, fell to spring level before autumn. There was no difference between monoculture cultivation and rotation in this respect. Since the total amounts of nitrogen $(0.3 \%)$ did not differ appreciably, it appears that neither nitrogen fertilizer application nor the clover-timothy ley had a long-term effect on nitrogen content in the soil in question.

Average grain yields over the entire trial period were, however, better for the rotation than the monoculture. The maximum yield in the rotation was obtained at a fertilization level of $800 \mathrm{~kg} / \mathrm{ha}$ and in the monoculture at a level of $1200 \mathrm{~kg} / \mathrm{ha}$. The favourable effect of crop rotation on yields was most obvious during the first year after the ley in unfertilized plots. The nitrogen uptake was also greater in the rotation than in the monoculture, indicating that the ley had improved the soil nitrogen condition. The less the fertilizer applied the more clover there was in the ley. While the nitrogen content of the soil may vary according to the proportion of legumes in the ley (CLEMENT 1961), the cultivation of legumes does not necessarily increase nitrogen content, although it always results in activation of the soil nitrogen (LYON 1930). In this study the amount of nitrogen released from decomposing clover-timothy ley was sufficient to increase the yield, but not large enough to affect the total nitrogen content of the soil. However, even during the second year after the ley, almost twice as much nitrogen mineralized in unfertilized plots compared with unfertilized plots of the monoculture. The amounts were the same order of magnitude as the amounts by which a clover ley increases the uptake of nitrogen by a grain crop, according to TEITTINEN (1965) and RAININKO (1968). KAILA (1952) also holds that red clover 
increases the amount of activated nitrogen, and that the effect is still apparent the second year after the clover ley.

Both the above-average yield and higher microbial activities indicate that the amount of actively mineralizing nutrients was greater in the rotation. In part this is because nitrogen-rich clover residues decompose more easily and the root biomass of clover-grass leys is greater than that of cereal crops. Thus, at the lowest levels of fertilization in the rotation, both biological nitrogen fixation and the hastening of decomposition improved the soil nitrogen conditon.

The proportion of clover in the ley also explains the higher dehydrogenase activities in the rotation at the lowest fertilization levels. Vegetation (plant residues) has been shown to have a clear effect on soil enzymatic activity (PANCHOLY \& RICE 1973). In short-term laboratory experiments it has been found that clover residues noticeably increase dehydrogenase activity (ABDEL-GHAFFAR et al. 1977). Dehydrogenase activity, which is considered to reflect the total microbiological activity of the soil, remained at a high level in the rotation at the lowest fertilization levels during the entire three-year period. At a fertilization level of $1200 \mathrm{~kg} / \mathrm{ha}$ in the rotation, when the amount of clover was less, activities were significantly lower during the same period. Dehydrogenase activity is known to be more susceptible to environmental variations than is microbial biomass (SMITH and PUGH 1979). Possibly at the highest fertilization level in the rotation it was affected by the slightly lowered $\mathrm{pH}$ value of the plots in question.

From several measurements made in the growing season, carbon dioxide was calculated to evolve at an average rate of $4.7 \mathrm{mmol} / \mathrm{m}^{2} / \mathrm{h}$ in the monoculture and $5.4 \mathrm{mmol} / \mathrm{m}^{2} / \mathrm{h}$ in the rotation. The rates are of the same order of magnitude as those calculated for a fertilized ley trial lasting several years (KUBICKA 1978). The correlation between the ATP content and evolution of carbon dioxide was highly significant. Although the amount of ATP is regarded as a measure of the microbial biomass, the correlation with test results measuring microbial activity indicates that in this case the amount of ATP reflects the active microbial biomass. Similar results have been obtained from forest soils (EILAND 1979).

Fertilization had a marked effect on the yield and much smaller effect on the microbiological results. Comparable results have been obtained in many long-term NPK fertilizer trials. Likewise microbial activity has not been found to vary significantly with level of fertilization (ABD-EL-MALEK et al. 1976, MÜLLER et al. 1979, EILAND 1980).

In cultivated soil, microbial activity is not limited by a deficiency of nutrients, but a lack of energy (available carbon substrates) (PERSON 1978). Fertilization increases the amount of plant debris and root secretions. These could most probably be of greater significance to microbes in the monoculture, where easily-decomposing organic material is less, than to microbes in the rotation. The effect of fertilization on cellulose decomposition and fluorescent pseudomonads is to be interpreted in this way: in the monoculture fertilizer applications appreciably increased the number of fluorescent pseudomonads and accelerated cellulose decomposition, but in the rotation, 
fertilization affected pseudomonads only a little and cellulose decomposition in fact slowed down. On the other hand, there was no difference between the two cropping systems in straw decomposition. The ploughing in of straw introduces a population that decomposes the straw if there is sufficient nitrogen available. The population does not appear to decline during the twoyear clover-timothy ley period.

VERSTRAETE and VOETS (1977) suggested on the basis of a long-term trial that, although no single characteristic examined reveals significant differences between the soil management practices, the total group of characteristics (enzyme activities, microbial counts etc.) clearly does. The present investigation also suggests certain characteristic features associated with fertilization and crop rotation: NPK fertilization has no more than a temporary effect on the soil nitrogen content, and the effect on micro-organisms is small. Crop rotation creates better conditions for microorganisms than does monoculture cultivation, by introducing easily-decomposing plant materials to the soil. These in turn, through the mediation of microbial activity, may have an effect on the yield.

\section{Acknowledgement}

The authors of this report are grateful for the encouragement and advice given throughout the study by Prof. Armi Kaila and Doc. Eva Eklund of the University of Helsinki.

\section{References}

ABDEL-GHAFFAR, A. S., EL-SHAKWEER, M. H. A. \& BAKARAT, M. A. 1977. Effect of organic matter and salts on the activity of some soil enzymes. Soil Organic Matter Studies 1: 319-324. Vienna.

ABD-EL-MALEK, Y., MONIB, M., RIZK, S. G. \& SHEHATA, S. M. 1976. Evaluation of some biological tests as parameters for microbial activities in soils. II. Z.bl. Bakt. Abt. II 131. 722-729.

ALTEN, F., WANDROWSKY, B. \& KNIPPENBERG, E. 1935. Beitrag zur Humusbestimmung. Ergebn. Agric.chem. 4: 66-67.

ANON. 1979. Microbial biomass in soil. Lumit application 508. Lumac Systems AG.

CLEMENT, C. R. 1961. Benefit of leys - structural improvement or nitrogen reserves. J. Brit. Grassl. Soc. 16: 194-200.

EILAND, F, 1979. An improved method for determination of adenosine triphosphate (ATP) in soil. Soil Biol. Biochem. 11: 31-35.

- 1980. The effects of manure and NPK fertilizers on the soil micro-organisms in a Danish long-term field experiment. Tidsskr. Pl.avl 84: 447-454.

JÄGGI, W. 1974. Bodenbiologische Untersuchungen in einem Düngungsversuch. Schw. Landw. Forsch. 13: 531-547.

KAILA, A. 1952. Influence of legumes upon soil fertility. Ann. Acad. Sci. Fenn. A II 42. 39 p.

KUBICKA, H. 1978. The effect of mineral fertilization on $\mathrm{CO}_{2}$ evolution in meadow soil. II. Pol. Ecol. Stud. 4: 167-178.

LYON, T. L. 1939. Legumes as a source of available nitrogen in crop rotations. Cornell Univ. Agric. Exp. Sta. Bull. 500. 22 p. 
MÜLLER, G., HICKISCH, B. \& MÜLLER, G., Jr. 1979. Bodenbiologische Änderungen in Dauerdüngungsversuchen unter besonderer Berücksichtigung des Versuches "Ewiger Roggenbau". Wiss. Beitr. Martin-Luther-Universität 14: 61-71.

PANCHOLY, S. K. \& RICE, E. L. 1973. Soil enzymes in relation to old field succession: amylase, cellulase, invertase, dehydrogenase and urease. Soil Sci. Soc. Amer. Proc. 37: 47-50.

PERSSON, J. G. 1978. Kulturátgärdernas inverkan på markorganismerna - markvård eller markförstöring? I. K. Skogs- o. Lantbr.akad. Tidskr. 117: 43-48.

RAININKO, K. 1968. The effects of nitrogen fertilization, irrigation and number of harvestings upon leys established with various seed mixtures. Acta Agr. Fenn. 112: 1-137.

SIMON, A., ROVIRA, A. D. \& SANDS, D. C. 1973. An improved medium for isolating fluorescent pseudomonads. J. Appl. Bact. 36: 141-145.

SMITH, S. N. \& PUGH, G. J. F. 1979. Evaluation of dehydrogenase as suitable indicator of soil microflora activity. Enz. Microb. Technol. 1: 279-281.

STEEL, R. G. D. \& TORRIE, J. H. 1960. Principles and procedures of statistics. p 107-109. New York.

TAYLOR, C. B. 1951. The nutritional requirements of the prominent bacterial flora of the soil. Proc. Soc. Appl. Microbiol. 14: 101-110.

TEITTINEN, P. 1965. Puna-apilan esikasviarvosta. Acta Agr. Fenn. 107: 175-190.

THALMANN, A. 1968. Zur Methodik der Bestimming der Dehydrogenaseaktivität im Boden mittels Triphenyltetrazoliumchlorid (TTC). Landw. Forsch. 21: 249-258.

VERSTRAETE, W. \&VOETS; J. P. 1977. Soil microbial and biochemical characteristics to soil management and fertility. Soil Biol. Biochem. 9: 253-258.

WITKAMP, M. 1966. Rates of carbon dioxide evolution from the forest floor. Ecology 47: 492-494.

Ms received October 4, 1982.

\title{
Lannoituksen ja kasvinvuorottelun vaikutus savimaan kemiallisiin ja biologisiin ominaisuuksiin
}

\author{
Aila Mettälä \\ Helsingin yliopisto, Mikrobiologian laitos 00710 Helsinki 71 \\ Maarit Koponen \\ Helsingin yliopisto, Maanviljelyskemian laitos, 00710 Helsinki 71 \\ Heikki Pirinen \\ Helsingin yliopisto, Mikrobiologian laitos, 00710 Helsinki 71 \\ Johan Korkman \\ Kemira Oy, PL 330, 00101 Helsinki 10
}

Työssä tutkittiin lannoitteiden pitkäaikaisen käytön ja kasvinvuorottelun vaikutuksia maan typpitilanteeseen ja mikrobiologiseen tilaan vuonna 1966 perustetussa kokeessa, jossa on lannoitustasot 0, 400, 800 ja 1200 kg/ha NPK (15 \% N) sekä monokulttuurissa että kiertoviljelyssä. Monokulttuurissa viljellään kevätvehnää, kierrossa timotei-apila -nurmea ja kevätvehnää. Vuosina 1979-81, jolloin tämä aineisto kerättiin, koko koealue oli vehnällä. 
Lannoituksella ja kasvinvuorottelulla ei ollut pysyvää vaikutusta maan mineraalitypen määrään, sillä keväisin ennen lannoitusta todettu alhainen taso saavutettiin syksyyn mennessä sekä monokulttuurissa että vuoroviljelyssä lannoitustasosta riippumatta. Nurmen edullinen jälkivaikutus oli kuitenkin ilmeinen, sillä keskisato koko kokeen ajalta oli vuoroviljelyssä parempi. Vielä toisena vuonna nurmen jälkeen vuoroviljelyssä mobilisoitui lannoittamattomilla ruuduilla lähes kaksinkertainen määrä typpeä monokulttuuriin verrattuna: $36.8 \mathrm{~kg} / \mathrm{ha}$ vuoroviljelyssä ja $21.0 \mathrm{~kg} / \mathrm{ha}$ monokulttuurissa.

Lannoitus lisäsi jonkin verran mikrobien määrä ja aktiivisuutta. Oljen hajoaminen tehostui ylimmälle lannoitustasolle saakka ja oli yhtä nopeaa monokulttuurissa ja vuoroviljelyssä. Eri lannoitustasoilla (0,400,800 ja $1200 \mathrm{~kg} / \mathrm{ha}$ NPK) oljesta hajosi kasvukauden aikana monokultturissa keskimäärin $24,29,34$ ja $38 \%$ ja vastaavasti $25,28,32$ ja $37 \%$ vuoroviljelyssä. Hiilidioksidia vapautui kasvukausina 1979-81 lannoittamattomilla ruuduilla keskimäärin $4.3 \mathrm{mmol} / \mathrm{m}^{2} / \mathrm{h}$ monokulttuurissa ja $4.9 \mathrm{mmol} / \mathrm{m}^{2} / \mathrm{h}$ vuoroviljelyssä, lannoitustasolla $400 \mathrm{~kg} / \mathrm{ha}$ vastaavasti $4.7 \mathrm{ja} 5.3 \mathrm{mmol} / \mathrm{m}^{2} / \mathrm{h}$. Ylimmillä lannoitustasoilla hiilidioksidia vapautui monokulttuurissa $5.0 \mathrm{mmol} / \mathrm{m}^{2} / \mathrm{h}$ ja vuoroviljelyssä $5.8 \mathrm{mmol} / \mathrm{m}^{2} / \mathrm{h}$. ATP:n määrä ja dehydrogenaasiaktiivisuus olivat suurimmillaan lannoitustasoilla 400 ja $800 \mathrm{~kg} / \mathrm{ha}$ ja vuoroviljelyssä jonkin verran suuremmat kuin monokulttuurissa. Lannoituksen ja kasvinvuorottelun biologista aktiivisuutta lisäävä vaikutus oli parhaimmillaankin vain joitakin kymmeniä prosentteja.

Tässä kokeessa kasvien kannalta edulliset olosuhteet suosivat myös maan mikrobitoimintaa. 